\title{
ENSINO JURÍDICO EMANCIPATÓRIO: A PEDAGOGIA DA LIBERTAÇÃO EM PAULO FREIRE E A SUPERAÇÃO DO BANCARISMO DOGMÁTICO TRADICIONAL DOS CURSOS JURÍDICOS
}

\author{
LUIZ GUSTAVO TIROLI \\ AdRIANA REgINA de Jesus SANTOS \\ Universidade Estadual de Londrina (UEL), Londrina, Paraná, Brasil
}

\begin{abstract}
Resumo: O presente artigo tem como objetivo refletir acerca do ensino jurídico tendo como parâmetro a Pedagogia Libertadora de Paulo Freire, a fim de problematizar as implicações da educação bancária na formação dos alunos do curso de Direito. Como metodologia, trata-se de uma abordagem qualitativa, em que se adotou a pesquisa bibliográfica. Nas considerações finais, tem-se que é possível superar o bancarismo na consolidação da emancipação tornando a formação do educando do curso jurídico mais humana na medida em que o ensino não é a transferência de saber e sim um encontro de sujeitos interlocutores.
\end{abstract}

Palavras-chave: Pedagogia Libertadora. Paulo Freire. Ensino Jurídico. Formação Humana.

\section{INTRODUÇÃO}

Os dilemas do ensino jurídico nacional são anunciados há décadas. Dentre as inúmeras facetas, destaca-se a ausência ou carência de formação dos professores dos cursos jurídicos para o exercício do magistério no Ensino Superior. A repetição de velhas práticas, o dogmatismo, o positivismo e o verbalismo são características dos primeiros cursos de Direito criados em território nacional e que se perpetuam na contemporaneidade, além da perspectiva bancária da educação jurídica.

De acordo com o educador Paulo Freire (2020), a educação bancária é a perspectiva em que o aluno é tido como mero receptor e armazenador do conteúdo narrado pelo professor. A relação educando-educador é distante, o docente é aquele que sabe e que ensina aquele que é tido como quem nada sabe. Por ter desenvolvido uma perspectiva teórico pedagógica, torna-se possível aplicar os ensinamentos freireanos aos diversos níveis e modalidades da educação, inclusive o Ensino Superior.

Isto posto, a problematização relativa à educação bancária proposta por Paulo Freire (2020) se demonstra atual no ensino jurídico, pois este foi criado e historicamente se consolidou em uma perspectiva de ensino baseada no dogmatismo e em uma prática de ensino vinculada à transmissão e armazenamento de conhecimento. Nesse sentido, o presente artigo tem como objetivo refletir acerca do ensino jurídico tendo como parâmetro a Pedagogia Libertadora proposta por Freire (2020), a fim de problematizar as implicações da educação bancária na formação de estudantes do curso de Direito. 
O método adotado é o hipotético-dedutivo. Como procedimento metodológico, trata-se de uma pesquisa com abordagem qualitativa, em se adotou a pesquisa bibliográfica, tendo como parâmetro os estudos dos seguintes autores: Bittar (2001); Dussel (1973); Freire (1976, 2000, 2016, 2020) e Rodrigues (1988, 1995, 2005), entre outros.

$\mathrm{Na}$ consecução do objetivo acima delineado, o artigo está dividido em três seções. Inicialmente, discorre-se sobre a trajetória e a concepção de educação bancária e libertadora de Paulo Freire. Em um segundo momento, reflete-se sobre o ensino jurídico nacional em uma perspectiva histórica, perquirindo sobre a prática docente e suas principais características contemporâneas, sobretudo em relação ao dogmatismo e a postura do professor diante da formação didático-pedagógica para o exercício do magistério no Ensino Superior. Por fim, no terceiro momento, destaca-se a necessidade da superação da educação bancária que permeia a prática docente no âmbito dos cursos jurídicos, tecendo considerações acerca das estratégias didático-pedagógicas que possam contribuir no processo de ensino e aprendizagem no contexto do ensino jurídico, tendo como parâmetro a Pedagogia Libertadora proposta por Paulo Freire (2020).

\section{A EDUCAÇÃO BANCÁRIA E A EDUCAÇÃO PROBLEMATIZADORA EM PAULO FREIRE}

Nascido em Pernambuco, no ano de 1921, apesar da situação de pobreza que vivenciou dado a crise financeira de 1929 e o falecimento do pai, Paulo Freire se formou pela Faculdade de Direito do Recife. Nunca desempenhou a advocacia, mas exerceu o magistério com afinco. Dedicou-se a educação de jovens e adultos, desenvolvendo um método de alfabetização que fora aplicado com êxito a 300 cortadores de cana em apenas 40 horas aula na cidade de Angicos, no Rio Grande do Norte. Em que pese ser conhecido pelo método de alfabetização, sua problematização repensa a própria teoria pedagógica, podendo ser aplicada e discutida em vários níveis e áreas do conhecimento.

Em 1959, prestou concurso e obteve o título de Doutor em Filosofia e História da Educação. Ficou exilado durante 16 anos por ocasião do golpe militar de 1964. Em 1969, tornou-se professor da Universidade de Harvard e, posteriormente, retornando ao Brasil, professor do Ensino Superior na Universidade Estadual de Campinas e na Pontifícia Universidade Católica de São Paulo, sendo ainda secretário de educação do município de São Paulo. Tornou-se um educador internacionalmente reconhecido, haja vista que recebeu aproximadamente 36 vezes o título de Doutor Honoris Causa. Paulo Reglus Neves Freire, patrono da educação brasileira, é tido como o maior educador brasileiro e um dos maiores do mundo (FREIRE, 1996).

A concepção filosófica freireana compreende o ser humano como um "ser das relações", capaz de apreender as contradições existentes entre o mundo social e o mundo natural, constituindo e consolidando a individualidade e a subjetividade não só, mas no coletivo, na interação e nos processos comuns da vida, uma vez que o processo educacional, na perspectiva freireana, é um trabalho coletivo, envolvendo educandos e educadores (VARGAS; LOCATELI; LOCATELI, 2019). A criação de espaços de cultura é imprescindível para a continuidade da ação dialógica constitutiva do processo educativo, 
TIROLI, L. G.; SANTOS, A. R. de J.

de modo que o educando possa representar a realidade apontando para possibilidades de transformação coletiva (COSTA, 2016).

Ao se debruçar sobre os estudos relativos à relação educador-educando, o pedagogo construiu uma crítica sólida contra a denominada educação bancária. Freire (2020, p. 79) denomina de bancária a perspectiva educacional que subjuga o discente como sujeito passivo da relação de ensino e aprendizagem, em que a atribuição do docente consiste em depositar o conteúdo, deixando a cargo do aluno a retenção, cabendo a este, ainda, devolver o conhecimento tal como fora transmitido por intermédio do processo avaliativo, que privilegia a memorização e a repetição dos conteúdos ministrados pelos professores.

A narração e a dissertação são técnicas fundamentais e recorrentes na prática de ensino brasileira, de modo que os conteúdos são retalhados da realidade e desconectados da totalidade do conhecimento, sendo o aluno transformado "em 'vasilhas', em recipientes a serem 'enchidos' pelo educador" (FREIRE, 2020, p. 80). Quanto mais se permite encher, melhor educando é; quanto mais consegue encher, melhor educador se torna.

Nessa educação bancária há uma constante contradição na relação educadoreducando: o primeiro é tido como o responsável por educar, o segundo aquele que é educado. Para Freire (2020), ninguém educa ninguém, nem mesmo o homem pode educar a si mesmo, assim, os homens são educados entre si, mediatizados pelo mundo.

Outra contradição é que o educador é aquele que sabe e o educando o que não sabe; o educador é aquele que diz, o educando aquele que ouve; o educador faz escolhas, o educando segue a prescrição; e o educador é o sujeito ativo do processo de ensino e aprendizagem, enquanto o educando é mero objeto (FREIRE, 2020). Tal perspectiva é diametralmente oposta à concepção que tem o aluno como epicentro do processo de "ensinagem", termo criado por Anastasiou em 1994 para demonstrar a prática crítica e complexa existente na relação professor-aluno, "englobando tanto a ação de ensinar quanto a de apreender" (ANASTASIOU; ALVES, 2005, p. 15).

“Na visão 'bancária' da educação, o 'saber' é uma doação dos que se julgam sábios aos que julgam nada saber" (FREIRE, 2020, p. 81). Assim, os educandos são os depositários, e o educador, o depositante. Na perspectiva da educação bancária, a prática de ensino prescinde da contextualização do conteúdo ministrado, ou seja, o docente não explica o objetivo, a origem ou o motivo de se estar dedicando tempo e recursos no estudo de determinado conteúdo, de modo que o processo de "ensinagem" se reduz a repetição e memorização de fórmulas e enunciados, mitigando a possibilidade de reflexão (OLIVEIRA; CARVALHO, 2010).

Assim, instaura-se uma confusão na mente do aluno fruto da descontextualização que leva, no âmbito do Ensino Superior, "muitos para a conclusão do curso quase por uma fatalidade e cada vez mais inseguros" (FÁVERO, 2002, p. 62). A fim de superar a visão bancária, o pedagogo vai propor a educação problematizadora, em que o fundamento é a dialógica e cuja função é humanizar e libertar: "A libertação autêntica, que é humanização em processo, não é uma coisa que se deposita nos homens. Não é uma palavra a mais, oca, mitificante. É práxis, que implica na ação e na reflexão dos homens sobre o mundo para transformá-lo" (FREIRE, 2020, p. 93).

Sendo assim, na perspectiva freireana, a educação problematizadora que se necessita hodiernamente deve ser "capaz de formar pessoas críticas, de raciocínio rápido, 
com sentido do risco, curiosas, indagadoras, não pode ser a que exercita a memorização mecânica dos educandos. A que 'treina', em lugar de formar" (FREIRE, 2000, p. 100). Dessa forma, o professor tem uma relação de companheirismo com os alunos, valorizando o pensamento autêntico, ato que é inviabilizado na perspectiva bancária, que é sempre "digestiva", de modo que pensar verdadeiramente é proibido (FREIRE, 2020).

A parceria estabelecida condiciona ambos a ocuparem um espaço de aprendizagem, tanto professor quanto aluno, fato que não minimiza a função do docente, ao contrário, engrandece, haja vista que se torna indispensável a transmissão do conhecimento não como outrora, mas como provocador, orientador e construtor do conhecido ao lado do aluno. A relação educando-educador e educador-educando supera a dicotomia hierárquica entre aquele que ensina e aquele que aprende, não comportando mais os argumentos de autoridade.

Nesse sentido, a historicidade é fundamental para a compreensão do homem na educação problematizadora, uma vez que os educandos se reconhecem como sujeitos inconclusos em um contexto histórico inacabado, rompendo o fatalismo da visão bancária, que coloca tudo como posto, e vocacionando o discente a ocupar os espaços de poder e agir criticamente na construção do conhecimento inacabado em um contexto social em transformação, tornando-o protagonista e não mero espectador.

Para tanto, o docente deve ter um amor profundo pelo discente e pelo mundo (FREIRE, 2016), não no sentido romântico ou usual, mas como um bem querer, uma responsabilidade do eu diante do outro (LÉVINAS, 2000), ou seja, uma responsabilidade ética e política que incorre no compromisso do professor com o desenvolvimento do aluno.

Segundo Freire (1976, p. 88), “o amor implica luta contra o egoísmo. Quem não é capaz de amar os seres inacabados não pode educar. Não há educação imposta, como não há amor imposto. Quem não ama não compreende o próximo, não o respeita". Tal perspectiva impele o educador a ocupar uma posição de aproximação e não de encobrimento, de diálogo e de escuta e não de imposição.

Na concepção bancária da educação o educador atua em dois momentos: primeiro na preparação da prática de ensino mediante o exercício do ato cognoscente em face do objeto cognoscível, e segundo, na transmissão dissertativa aos educandos em relação ao objeto sobre o qual exerceu anteriormente o ato cognoscente. Na visão problematizadora não há dicotomia entre os momentos, assim, em ambos, o educador é sujeito cognoscente, tanto quando prepara como quando se apresenta diante dos alunos em uma ação dialógica. Assim, o educando, outrora concebido como mero receptor do ato narrativo, sendo tido como objeto, passa a sujeito e protagonista no processo de "ensinagem", tornando-se investigador crítico (FREIRE, 2020).

A perspectiva bancária da educação não se aplica somente à Educação Básica, mas também ao Ensino Superior, ambiente histórico e tradicionalmente ocupado por elites que visam manter a sociedade e as camadas populares afastadas, por intermédio do encastelamento dos intelectuais e do distanciamento das reflexões, das pesquisas e das práticas de ensino da realidade social. 
TIROLI, L. G.; SANTOS, A. R. de J.

Nesse sentido, o recorte teórico deste ensaio tem como base os cursos de Direito, tendo como foco compreender a perspectiva histórica de fundação e a prática docente no âmbito do Ensino Superior, podendo, dessa forma, perceber a relação com o bancarismo educacional denunciado por Paulo Freire, como discutido a seguir.

O ENSINO JURÍDICO NACIONAL: apontamentos históricos e prática docente

Os primeiros cursos de bacharelado em Direito foram instituídos em 1827 por Dom Pedro I, em São Paulo e Olinda (posteriormente transferido para Recife, em 1854), por intermédio da Carta de Lei no. 1.827, de 11 de agosto de 1827 (BASTOS, 2000). A intenção era formar quadros que pudessem compor o estamento burocrático no intuito de consolidar o processo de independência do país, formando magistrados, deputados, senadores, diplomadas e administradores. Todavia, a autonomia que se esperava não se concretizou, uma vez que os conteúdos, as práticas pedagógicas e a vivência acadêmica foram importadas da metrópole portuguesa, principalmente da Universidade de Coimbra (SCHWARCZ, 1993, p. 106).

Nesse contexto histórico, a preocupação principal consistia em garantir a conservação do modelo estatal vigente, impossibilitando o desenvolvimento de posições críticas ao Império do Brasil. Durante 1828 e 1870, os cursos jurídicos eram os principais responsáveis pela formação dos intelectuais brasileiros que ocupavam os cargos centrais no governo (MACIEL, 2017).

Para tanto, os currículos e os conteúdos eram fixados de acordo com os interesses do Estado e com o intuito de formar profissionais que pudessem cumprir tal finalidade. Portanto, tem-se o perfil do bacharel formado pelos cursos jurídicos primordiais, um indivíduo politicamente alinhado aos "fundamentos ideológicos do Estado; criteriosamente profissionalizado para concretizar o funcionamento e o controle do aparato administrativo; e habilmente convencido se não dá legitimidade, pelo menos da legalidade da forma de governo instaurada" (ADORNO, 2019, p. 105).

Nesse período, os lentes catedráticos (professores) estabeleciam uma relação formal e autoritária com os alunos, de modo que a aula expositiva consistia na leitura de trechos da legislação com pausas para comentários realizados pelos docentes que, conforme Bittar (2001, p. 87), eram "escolhidos para serem os portadores da palavra jurídica", mas que "não eram necessariamente didatas". As características do ensino jurídico dessa época eram o predomínio do direito natural até meados de 1870; aulas ao estilo conferência; controle dos cursos pelo governo central e formação de elites desconectadas da realidade política e social do país (RODRIGUES, 1995).

Com o advento da República, o positivismo passou a nortear o ensino jurídico nacional, uma filosofia que "expressa confiança nos benefícios da industrialização, no otimismo em relação ao progresso capitalista, no culto à ciência e a valorização do método científico, voltados a uma reforma intelectual da sociedade" (OLIVEIRA, 2010, p. 9). O ensino jurídico não era muito diferente de alguns aspectos da realidade atual, marcado pelo dogmatismo, currículo extremamente conservador e aulas expositivas baseadas em códigos comentados (OLIVEIRA; GEBRAN, 2018, p. 316).

Nesse período, os egressos dos cursos jurídicos passam a ocupar outros espaços, atuando de forma autônoma (MACHADO, 2009), gerando ampla demanda social pela abertura de novos cursos de Direito no contexto das transformações econômicas e da 
industrialização tardia, rompendo, assim, o monopólio dos dois cursos primordiais, passando o ensino jurídico nacional por reformas pouco significativas. Mais adiante, a Constituição Federal de 1988 trouxe a educação enquanto direito fundamental, voltada à formação e qualificação para o mercado de trabalho e para o exercício da cidadania, impactando o ensino jurídico.

Apesar do transcorrer histórico, persistem hodiernamente os problemas relacionados ao ensino jurídico. Assim, a crise crônica do ensino jurídico pode ser dividida em três aspectos: a) estrutural, relativa à concepção epistemológica do conhecimento jurídico no âmbito político-ideológico; b) funcional, que diz respeito a atuação pragmática e a identidade dos operadores do direito dentro do mercado de trabalho; e c) operacional, vinculada à concepção administrativa e acadêmica da formação de juristas, sobretudo no âmbito didático-pedagógico e curricular (RODRIGUES, 2005).

Para Rodrigues (1988), as mudanças estruturais e institucionais em relação ao curso de Direito, tais como a inserção de disciplinas introdutórias e a regulamentação dos currículos, não foram suficientes para garantir a qualidade do ensino jurídico. Para esse autor, persistiram antigas práticas pedagógicas herdadas da Universidade de Coimbra, com foco em aulas expositivas alicerçadas em revisão bibliográfica e legal.

Sá Neto e Menezes (2019) apontam que um dos problemas centrais dos cursos de Direito consiste na pouca qualificação do corpo docente, que utiliza técnicas didáticas predominantemente expositivas e pouco reflexivas. Para Filho (1979, p. 14), "a renovação do ensino jurídico, na sociedade tecnológica, depende muito mais da mudança de atitudes dos professores e alunos do que de qualquer outro fator que se queira atribuir". Assim, pode-se concluir que os dilemas do ensino jurídico estão relacionados, inclusive, com as práticas de ensino e a precária formação didáticopedagógica dos docentes, consolidando, assim, uma perspectiva bancária de educação jurídica.

Assim sendo, em que pese as inúmeras facetas da crônica crise do ensino jurídico, o objeto de reflexão deste artigo consiste em discutir o papel do docente no processo de ensino e aprendizagem desenvolvido no âmbito dos cursos jurídicos nacionais. Sustenta-se a adoção de uma postura política emancipatória em detrimento da concepção bancarista dogmática tradicional que permeia a prática do ensino jurídico brasileiro histórico e institucionalmente.

No ensino jurídico dogmático tradicional, ao invés de comunicar-se, o educador faz comunicações por intermédio do discurso, cabendo aos educandos o arquivamento desses comunicados. "Eis aí a concepção 'bancária' da educação, em que a única margem de ação que se oferece aos educandos é a de receberem os depósitos, guardálos e arquivá-los" (FREIRE, 2020, p. 80-81). Para Luckesi (2005), os alunos não são concebidos como sujeitos históricos inseridos em um contexto e, consequentemente, mais se classifica do que se ensina.

Dessa forma, o bancarismo do ensino jurídico tem raízes na prática docente que historicamente se alicerçou em estratégias desconectadas da realidade, corroborando a deficiência da formação didático-pedagógica para consolidação desse fenômeno no âmbito dos cursos de Direito. Nessa lógica, repensar o fazer pedagógico é necessário 
TIROLI, L. G.; SANTOS, A. R. de J.

para superar o bancarismo dogmático tradicional dos cursos jurídicos. Destarte, a Pedagogia Libertadora proposta por Freire (2020) pode ser de suma importância para se construir uma perspectiva de superação do paradigma bancário por uma perspectiva libertadora e emancipatória.

O ENSINO JURÍDICO LIBERTADOR E EMANCIPATÓRIO EM DETRIMENTO DO BANCARISMO DOGMÁTICO TRADICIONAL DOS CURSOS JURÍDICOS

O bancarismo dogmático tradicional que permeia a prática de ensino no âmbito dos cursos jurídicos tem raízes na importação de estratégias da metrópole portuguesa quando da instalação dos primeiros cursos em território nacional, uma ação docente baseada em aulas expositivas, em que o discente não tem espaço para interagir, e no dogmatismo, que impossibilita a reflexão crítica entorno do instituto, cabendo ao aluno apenas a assimilação do conteúdo, estilo em que "muitos cursos ainda seguem mergulhados [...]" (FRANCISCHETTO, 2018, p. 8). Nesse sentido, esta seção discute, a partir de oito pontos, os aspectos do bancarismo do ensino jurídico, tecendo críticas e propondo reflexões para mitigação do modelo tradicional em detrimento do modelo emancipatório.

O primeiro ponto a ser enfrentado diz respeito à finalidade do ensino jurídico. $O$ curso de bacharelado em Direito não pode ser concebido como curso de "advocacia" ou ser reduzido a mero cursinho preparatório para concurso (NUNES, 2005). A formação holística, crítica e reflexiva do discente do curso de Direito deve ser balizada pelas ciências jurídicas, haja vista que incontáveis cidadãos notáveis se formaram, sem, contudo, terem exercido a advocacia, tal como a escritora Clarice Lispector e o pedagogo Paulo Freire, denotando que o curso deve ser capaz de oferecer o desenvolvimento de habilidades relativas à leitura, interpretação, dialogicidade e criticidade.

Na perspectiva emancipatória, o bacharelado em Direito é concebido como um curso capaz de formar cidadãos críticos e pensantes para atuar como agentes transformadores da realidade social, dentro ou fora do âmbito jurídico. Portanto, não se pode conceber os cursos de direito como "indústrias" preparadoras de mão-de-obra para o mercado de trabalho, pois corre-se o risco de transformar a reflexão, produção de conhecimento científico e a transformação social em "falácias ou simbologias retóricas constantes em diretrizes do Ensino Superior" (SIQUEIRA, 2016, p. 75).

A concepção bancária do ensino jurídico mitiga essa finalidade do bacharelado em Direito, de modo que o torna um curso alicerçado na repetição e memorização de leis, institutos e brocados em latim que serão atestados por exames de múltipla escolha, cujo intuito consiste em formar operadores do Direito, sujeitos capazes de atuar na manutenção do sistema jurídico, sem, contudo, ter capacidade de repensá-lo, ressignificá-lo e reestruturá-lo.

“Nestes termos a formação do bacharel é entendida como uma acumulação progressiva de informações, limitando-se o aprendizado a uma reprodução de teorias que parecem desvinculadas da prática [...]" (FERRAZ JÚNIOR, 1979, p. 70). Na perspectiva da educação jurídica bancária, o docente reifica o discente à medida que exige a repetição do conteúdo ministrado. 
Assim, tem-se o segundo ponto a ser discutido: o processo avaliativo. O sistema avaliativo tradicional corrobora para o bancarismo ao resumir-se basicamente em provas e avaliações elaboradas com questões de múltipla escolha, cuja tarefa do aluno consiste em rememorar datas, prazos, termos, letra da lei e, assim, assinalar uma das opções apresentadas, um método que facilita o trabalho docente na correção massiva das provas, inclusive nos exames para o exercício da advocacia e concursos públicos. Dessa forma, a avaliação é o extrato daquilo que anteriormente foi depositado. Ainda que o discente tenha a convicção de "alternar o Direito, memorizar e repetir são as únicas saídas possíveis, já que serão essas as atividades mentais cobradas de maneira coativa nas avaliações" (MARTíNEZ, 2002, p. 18).

Ao contrário, na perspectiva emancipatória do ensino jurídico, o sistema avaliativo deve ser compreendido como uma estratégia didático-pedagógica que contribui para a formação do aluno, ocorrendo de maneira permanente durante o desenvolvimento da disciplina, privilegiando questões abertas que permitam a expressão do aluno em relação ao conteúdo explorado em parceria com o professor. Exercícios e atividades que possibilitem a reflexão crítica em torno dos institutos, das normas, das decisões judiciais, dos casos concretos, das situações problema que exijam do discente capacidade analítica, interpretativa e propositiva.

$\mathrm{O}$ terceiro ponto diz respeito às estratégias didático-pedagógicas dos docentes que não podem ser concebidas como ato de deliberação ou preferência subjetiva. Tendo o aluno como centro do processo de "ensinagem", torna-se fundamental compreender que os recursos didáticos utilizados pelos professores devem estar de acordo com as necessidades dos alunos, considerando seus conhecimentos prévios e sua visão de mundo. "Essa estratégia pedagógica se baseia no pressuposto de que todos levamos à sala de aula um conhecimento que vem da experiência e de que, esse conhecimento pode, de fato, melhorar a nossa experiência de aprendizado" (HOOKS, 2013, p. 114).

Assim, a prática de ensino emancipatória vai ao encontro do aluno; não se utiliza esse ou aquele recurso de acordo com o perfil do docente, mas em consonância às condições de aprendizagem do discente, uma vez que o trabalho do professor não é aquele desenvolvido consigo mesmo, mas com os alunos, ou seja, valorizando a visão de mundo que os discentes trazem para dentro da sala de aula e atendendo, assim, as particularidades e a realidade política, social, econômica, cultural e geracional da turma (FREIRE, 2020).

O quarto ponto a ser discutido diz respeito à linguagem jurídica. Ou seja, o dialeto excessivamente rebuscado, composto por expressões em latim, brocados jurídicos e termos técnicos que corroboram para a manutenção do campo jurídico e servem para separar aqueles que sabem daqueles que não sabem, estabelecendo, de maneira clara, os limites dessa divisão.

$\mathrm{Na}$ prática libertadora, o docente está atento a elaborar e colaborar com a significação do termo de acordo com o contexto que se apresenta em sala de aula, possibilitando que os alunos possam se apropriar, sem, contudo, excluí-los ou marginalizá-los, mas acolhendo-os em uma função humanizadora do processo de "ensinagem". Entretanto, mesmo assim, é preciso ter em vista que a linguagem jurídica 
TIROLI, L. G.; SANTOS, A. R. de J.

não é cidadã. Conforme Bourdieu (2003), ela é um instrumento de manutenção do capital jurídico, corroborando para distinguir aqueles que pertencem daqueles que não pertencem ao campo jurídico.

O quinto ponto destacado sobre o ensino jurídico libertador consiste na problematização da prática docente que se apresenta como neutra ou apolítica. Assim, torna-se fundamental superar a epistemologia da neutralidade, que trata os sujeitos sem considerar a sexualidade, a etnia, a classe social, a língua, a espiritualidade, o gênero, etc, haja vista que tal perspectiva diz respeito a um conhecimento surdo e sem rosto (GROSFOGUEL, 2008, p. 65). O docente dos cursos jurídicos precisa perceber a manifestação diversa e plural dos alunos, ter responsabilidade pelo outro que se manifesta.

Na visão emancipadora, considera-se que o próprio Direito não é neutro. $\mathrm{O}$ discurso pós-político e descomprometido cobre a ideologia dominante daqueles que política, econômica e historicamente ocuparam os espaços de poder e construíram o Direito para cumprir a finalidade de garantir a manutenção desse poder. Ou seja, os conteúdos e valores não são neutros por se esconderem sobre esse manto, por isso, torna-se fundamental um ensino jurídico libertador e emancipatório que seja capaz de questionar, criticar e ressignificar os institutos e as teorias clássicas.

Efetivamente, não se pode compreender o sistema democrático e a liberdade de expressão com uma aula expositiva excessivamente monolítica, centralizada na figura docente, tanto quanto não se poderá conceber o respeito às minorias sem uma efetiva fala daqueles que se encontram na posição de minoria histórica. Assim, o ordenamento jurídico instaurado a partir da Constituição Federal de 1988 é necessariamente democrático, plural, inclusivo e participativo; não poderá haver ensino jurídico que possa dessoar da axiologia própria do sistema normativo constitucional.

Um sexto ponto diz respeito às disciplinas propedêuticas. Assim, vale ressaltar a importância das disciplinas introdutórias nos cursos de Direito que, por vezes, são negligenciadas, substituídas, aglutinadas ou postas no final do curso quando o discente está preocupado com o exame da $\mathrm{OAB}$, com a entrega e apresentação do trabalho de conclusão, com as horas complementares, com o estágio curricular obrigatório e outras atribuições, fazendo, assim, com que a discussão fundamental sobre a teoria do direito, a filosofia e a sociologia jurídica, a psicologia, a antropologia, a economia e as outras disciplinas fundamentais não tenham o trato necessário para formar juristas, focando, quase que exclusivamente, na formação de operadores do Direito (termo muito apropriado para uma visão bancarista dogmática tradicional do ensino jurídico).

A formação humanista do discente se perfaz pelas disciplinas introdutórias ou propedêuticas. Assim, uma prática docente emancipatória compreende a necessidade de aprofundar os conhecimentos e relacioná-los com a realidade concreta dos alunos, interagindo e construindo um diálogo consciente, problematizador e crítico que supere a ingenuidade.

O sétimo ponto ressalta a importância da formação docente. Assim sendo, almeja-se uma formação pedagógica consciente, intencional e propositiva, capaz de superar o bancarismo dogmático tradicional do ensino jurídico. O compromisso do docente não é ser mero transmissor do conhecimento, deixando a cargo do aluno a retenção, mas promover situações-problema complexas que possibilitem a construção do conhecimento profundo e sólido (MORAES; LIMA, 2017). Para Dussel (1973): 
todo professor deve ensinar mais do que simplesmente já foi dado anteriormente; deve ensinar criticamente como isso foi alcançado; não transmite o tradicional como tradicional, mas revive as condições que o tornaram possível tão novo, tão único, como a criação (DUSSEL, 1973, p. 142, tradução nossa)'.

Para tanto, a formação docente é fundamental, desde a graduação, passando pelos programas de pós-graduação lato e stricto sensu, os cursos livres e os programas de formação continuada, que devem garantir uma formação ética e estética que constitua uma docência comprometida com o processo de "ensinagem" e um professor empenhado em desenvolver capacidades psíquicas e humanas garantidoras da formação do discente como ser social sensível e consciente do contexto em que está inserido.

A emancipação ocorre à medida que se abre espaço para a manifestação da vítima, do oprimido, permitindo que este ocupe o centro do processo de construção dos conhecimentos ministrados, permitindo que fale e que seja ouvido não como mero receptor, mas como agente pensante, como fonte de conhecimento histórico e político (LIMA; PERNAMABUCO, 2018).

Assim, a formação do docente é fundamental para a superação dos dilemas históricos do ensino jurídico nacional, haja vista que a falta de preparação didáticopedagógica dos docentes corrobora para a consolidação do ensino jurídico bancário. Dessa forma, torna-se necessário uma formação que possibilidade a reflexão crítica em torno do fazer docente, consolidando uma prática alicerçada na desconstrução do modelo bancário em detrimento do modelo problematizador, uma vez que o docente deve abandonar "o papel de detentor do conhecimento e enfrentaria as narrativas jurídicas como possibilidades que devem ser relacionadas com a realidade vivida" (ZANARDI, 2009, p. 1270).

Por fim, o oitavo ponto discute sobre a prática docente. Cumpre ressaltar que o ensino nos cursos jurídicos, enquanto campo do conhecimento ligado às ciências sociais aplicadas, proporciona a construção, de maneira singular em relação aos outros cursos, da prática docente libertadora, crítica, reflexiva e propositiva, uma vez que o docente poderá se valer de instrumentos ínsitos ao próprio saber jurídico, tais como a possibilidade de discutir teses doutrinárias, pois teóricos e doutrinadores divergem acerca de determinados temas, institutos e interpretações por meio da denominada doutrina majoritária e minoritária, possibilitando que os alunos possam participar ativamente, tomando posição e refletindo.

Nesse sentido, é possível ainda discutir jurisprudências conflitantes, até mesmo súmulas vinculantes e entendimentos dominantes, de modo a conduzir o discente a perceber que o Direito não é um dado posto, mas um construto histórico elaborado e interpretado por agentes detentores de capital jurídico, político, econômico, cultural e social. Portanto, a narrativa conservadora e dogmática que tenha o intuito de justificar a ordem jurídica vigente inviabiliza "toda e qualquer explicitação do Direito por um processo dinâmico, inserido no bojo dos conflitos sociais e correlações de força" (WOLKMER, 2015, p. 30), podendo as discussões a respeito das decisões contribuir para romper essa perpetuação. Ainda é fundamental o questionamento de leis e atos 
TIROLI, L. G.; SANTOS, A. R. de J.

normativos baseado em princípios constitucionais, na valorização de uma percepção do ordenamento jurídico como sistema uno e integralizado em torno da Constituição Federal, e outras estratégias didático-pedagógicas que estão ao alcance do docente na prática cotidiana.

Dessa forma, muito pode ser realizado pelo docente em sala de aula para superar o bancarismo dogmático tradicional na construção do ensino jurídico emancipador, uma vez que "em uma perspectiva de educação libertadora, deve-se procurar compreender criticamente as razões desse problema e assumir-se sujeito de sua transformação, ao invés de esperar que de fora venha a mudança" (COSTA, 2016, p. 99).

A conjugação e indissociabilidade entre ensino, pesquisa e extensão é fundamento da pedagogia jurídica conscientizadora que visa garantir um ensino teórico crítico efetivado com o perene contato com a realidade. Assim, outra estratégia docente consiste em possibilitar que o discente não apenas complemente, mas de fato concretize o processo de aprendizagem por intermédio dos projetos de extensão promovidos pelas Instituições de Ensino Superior, garantindo, assim, uma formação holística e integrada, de modo que a teoricidade crítica da sala de aula possa encontrar respaldo no enfrentamento da realidade, superando, inclusive, a dicotomia histórica entre a teoria e a prática de maneira consciente e reflexiva (PEREIRA; SILVA, 2019).

Sendo assim, verificado os aspectos do bancarismo e do dogmatismo jurídico tradicional dos cursos de Direito, cumpre destacar, sobretudo, a prática e a formação docente enquanto fundamentos da superação do modelo tradicional na consecução do modelo emancipatório, tendo em vista que a carência de formação adequada impele o docente a repetir velhas práticas no eterno retorno do mesmo, sem repensar e criticar o fazer pedagógico, consolidando a perspectiva bancária. Em que pese as inúmeras dificuldades, muito pode ser realizado pelo docente para transformação dessa realidade, primeiro buscando formação didático-pedagógica para o exercício do magistério e, segundo, ressignificando a prática docente em sala de aula, na concretização do ensino jurídico libertador e emancipatório.

\section{CONSIDERAÇÕES FINAIS}

Em relação ao questionamento central do trabalho, tem-se que uma análise do ensino jurídico sob a perspectiva da educação bancária de Paulo Freire é uma leitura atual, necessária e pertinente. Assim, a partir dos conceitos operacionais extraídos da teoria freireana e da literatura pertinente ao assunto, constata-se que o bancarismo dogmático tradicional dos cursos jurídicos, não muito diferente do que sempre fora historicamente, quando da criação dos primeiros cursos em território nacional, é uma realidade contemporânea.

A consolidação do ensino jurídico emancipador em detrimento do bancarismo depende, em muito, da ação docente, da postura do professor diante dos alunos, haja vista que, como faceta da crise crônica do ensino jurídico, a falta de preparo didáticopedagógico dos docentes dos cursos jurídicos corrobora para a manutenção da realidade hodierna.

Ou seja, pode-se concluir que o descaso ou a ausência de formação para o exercício do magistério tem sido uma das causas do modelo bancário do ensino jurídico, 
de modo que o professor negligencia o fazer docente, não adotando uma postura crítica, reflexiva e propositiva, tendo o aluno como epicentro do processo de "ensinagem", o que implica na formação do estudante do curso de Direito.

O ensino jurídico bancário contribui para a manutenção da formação de bacharéis baseada na competência técnica para atuar nos modos de produção de maneira alienada (FRIGOTTO, 2010). Em contraposição a isso, Libâneo (2004) expõe que, de forma contra hegemônica, a tendência libertadora desenvolvida sobre a tese freiriana se distancia daquelas que se voltam apenas para a fragmentada reprodução de saberes instituídos.

Assim, atribui-se ao educador e, em específico, à prática pedagógica, a necessidade da contradição. Neste processo, o educador caminha em um sentido no qual vai relacionando a dialética com a própria ação, ou seja, atua de forma a pensar sobre suas ações, buscando o entendimento e a transformação sobre o ser e o fazer docente, tendo como premissa o que faz, como faz e porque faz, levando em consideração a consciência sobre suas práticas.

Artigo recebido em: 15/02/2021

Aprovado para publicação em: 29/06/2021

EMANCIPATORY LEGAL EDUCATION: THE PEDAGOGY OF LIBERATION IN PAULO FREIRE AND THE OVERCOMING OF TRADITIONAL DOGMATIC BANKING OF LEGAL COURSES

ABSTRACT: This article aims to reflect on legal education with Paulo Freire's Liberating Pedagogy as a parameter, in order to problematize the implications of banking education in the training of law students. As a methodology, it is a qualitative approach, in which bibliographical research was adopted. In the final considerations, it is possible to overcome banking by consolidating emancipation, making the education of the legal student more humane in that teaching is not the transfer of knowledge, but a meeting of interlocuting subjects.

KEYWORDS: Liberating Pedagogy. Paulo Freire. Legal Education. Human Formation.

EDUCACIÓN JURÍDICA EMANCIPATIVA: LA PEDAGOGÍA DE LA LIBERACIÓN EN PAULO FREIRE Y LA SUPERACIÓN DE LA BANCA DOGMÁTICA TRADICIONAL DE CURSOS JURÍDICOS

RESUMEN: Este artículo pretende reflexionar sobre la educación jurídica con la Pedagogía Liberadora de Paulo Freire como parámetro, para problematizar las implicaciones de la educación bancaria en la formación de estudiantes de Derecho. Como metodología, es un enfoque cualitativo, en el que se adoptó la investigación bibliográfica. En las consideraciones finales, es posible superar el "bancarismo" consolidando la emancipación, humanizando la formación del 
TIROLI, L. G.; SANTOS, A. R. de J.

estudiante de Derecho en la medida en que la enseñanza no es la transferencia de conocimientos, sino un encuentro de materias interlocutoras.

PALABRAS CLAVE: Pedagogía Liberadora. Paulo Freire. Educación Jurídica. Formación Humana.

NOTAS

1 - No original: “Todo maestro debe enseñar más que lo simplemente ya dado con anterioridad; debe enseñar con modo crítico el cómo eso fue alcanzado; no transmite lo tradicional como tradicional, sino que revive las condiciones que hicieron posible como nuevo, como único, como creación".

\section{REFERÊNCIAS}

ADORNO, Sérgio. Os aprendizes do poder: o bacharelismo liberal na política brasileira. 2. ed. rev. São Paulo: EDUSP, 2019.

ANASTASIOU, Léa das Graças Camargos; ALVES, Leonir Pessate (org.). Processos de ensinagem na universidade: pressupostos para as estratégias de trabalho em aula. 5. ed. Joinville: Univillie, 2005.

BASTOS, Aurélio Wander. O ensino jurídico no Brasil. 2. ed. Rio de Janeiro: Lumen Juris, 2000.

BITTAR, Eduardo Carlos Bianca. Direito e ensino jurídico: legislação educacional. São Paulo: Atlas, 2001.

BOURDIEU, Pierre. O poder simbólico. 6. ed. Rio de Janeiro: Bertrand Brasil, 2003.

COSTA, Bruno Botelho. Paulo Freire: educador-pensador da libertação. Pro-Posições, Campinas, v. 27, n. 1, p. 93-110. Jan./abr. 2016. Disponível em: $<$ https://periodicos.sbu.unicamp.br/ojs/index.php/proposic/article/view/8645900 >. Acesso em: 14 jan. 2021.

DUSSEL, Enrique. Para una ética de la liberación latino-americana. Tomo I. Córdoba: Siglo XXI e Latinoamérica Livros, 1973.

FÁVERO, Maria de Lourdes de Albuquerque. Universidade e estágio curricular: subsídios para discussão. In: ALVES, NILDA (org.). Formação de professores: pensar e fazer. 7. ed. São Paulo, SP: Cortez, 2002. p. 53-71. 
FERRAZ JÚNIOR, Tércio Sampaio. O ensino jurídico. In: VENÂNCIO FILHO, Alberto (org.); ALBUQUERQUE, Guiomar Freitas de. Encontros da UnB: ensino jurídico. Brasília: Universidade de Brasília, 1979. p. 69-86.

FILHO, Álvaro Melo. Metodologia do ensino jurídico. 2. ed. Rio de Janeiro: Forense, 1979.

FRANCISCHETTO, Gilsilene Passon Picoretti. Apresentação. In: ABIKAIR NETO, Jorge. Educação jurídica e formação de professores. Curitiba: Juruá, 2018. p. 7-12.

FREIRE, Ana Maria Araújo. A trajetória de Paulo Freire. In: GADOTTI, Moacir (org.). Paulo Freire: uma bibliografia. São Paulo: Cortez, 1996. p. 27-64.

FREIRE, Paulo. Educación y cambio. Buenos Aires: Búsqueda-Celadec, 1976.

FREIRE, Paulo. Pedagogia da autonomia. Rio de Janeiro: Paz e Terra, 2016.

FREIRE, Paulo. Pedagogia da indignação: cartas pedagógicas e outros escritos. São Paulo, SP: Editora UNESP, 2000.

FREIRE, Paulo. Pedagogia do oprimido. 74. ed. São Paulo: Paz e Terra, 2020.

FRIGOTTO, Gaudêncio. Qualidade e quantidade da educação básica no Brasil: concepções e materialidade. Rio de Janeiro, 2010.

GROSFOGUEL, Ramón. Para descolonizar os estudos de economia política e os estudos pós-coloniais: Transmodernidade, pensamento de fronteira e colonialidade global. Revista Crítica de Ciências Sociais, Coimbra, s. v., n. 80, p. 115-147, mar. 2008. Doi: <https://doi.org/10.4000/rccs.697>. Disponível em: <shorturl.at/ejrvC>. Acesso em: 12 jan. 2021.

HOOKS, Bell. Ensinando a transgredir: a educação como prática da liberdade. São Paulo: Martins Fontes, 2013.

LÉVINAS, Emmanuel. Totalidade e infinito. Trad. José Pinto Ribeiro. Rev. Artur Mourão. Lisboa: Edições 70, 2000.

LIBÂNEO, José Carlos. Organização e gestão da escola: teoria e prática. 5. ed. Goiânia: Editora Alternativa, 2004.

LIMA, José Gllauco Smith Avelino de; PERNAMBUCO, Marta Maria Castanho Almeida. Horizontes pós-coloniais da Pedagogia do Oprimido e suas contribuições para os estudos curriculares. Revista Brasileira de Educação, Rio de Janeiro, v. 23, s. n., p. 1-24, 
TIROLI, L. G.; SANTOS, A. R. de J.

2018. Doi: $\quad<$ http://dx.doi.org/10.1590/S1413-24782018230063 $>$. Disponível em: <shorturl.at/ghDI5 >. Acesso em: 11 jan. 2021.

LUCKESI, Cipriano Carlos. Avaliação da aprendizagem escolar: estudos e proposições. 17 ed. São Paulo: Cortez, 2005.

MACHADO, Antônio Alberto. Ensino jurídico e mudança social. 2. ed. São Paulo: Expressão Popular, 2009.

MACIEL, Richard Crisóstomo Borges. Ensino jurídico positivista e a pedagogia de Warat. Curitiba: Juruá, 2017.

MARTÍNEZ, Sérgio Rodrigo. Pedagogia jurídica: do ensino tradicional à emancipação. Curitiba-PR: Juruá, 2002.

MORAES, Dirce Aparecida Foletto de; LIMA, Claudia Maria de. A reconstrução da prática docente: reflexos na intervenção em uma experiência didática. Revista Profissão Docente, Uberaba, v. 17, n. 36, p. 55-65, jan.- jul., 2017.

NUNES, Rizzatto. Manual de introdução ao estudo do direito: com exercícios para a sala de aula e lições de casa. 6. ed. rev. atual. e ampl. São Paulo: Saraiva, 2005.

OLIVEIRA, Claudemir Gonçalves de. A matriz positivista na educação brasileira: uma análise das portas de entrada no período Republicano. Diálogos Acadêmicos - Revista Eletrônica da faculdade Semar/Unicastelo, Sertãozinho-SP, v. 1, n. 1, p. 1-17, Edição Out./Jan., 2010.

OLIVEIRA, José Sebastião de; CARVALHO, Thomaz Jefferson. Aspectos da crise do ensino jurídico no Brasil e a visão de Paulo Freire. Revista Jurídica Cesumar - Mestrado, Maringá-PR, v. 10, n. 2, p. 567-589, jul./dez. 2010.

OLIVEIRA, Patrícia Zaccarelli; GEBRAN, Raimunda Abou. O profissional docente do direito: refletindo sobre sua prática pedagógica. HOLOS, Natal, ano 34, v. 3, s. n., p. 314-336, 2018. Disponível em: <shorturl.at/noC09>. Acesso em: 13 set. 2020.

PEREIRA, Flávia Souza Máximo; SILVA, Flávia Coelho Augusto. Teoria e prática no ensino jurídico: diálogo entre decolonidade do saber e pedagogia da libertação de Paulo Freire e Bell Hooks. Revista de Direito da Faculdade Guanambi, Guanambi, v. 6, n. 1, e236, p. 1-20, jan./jun. 2019. Disponível em: <shorturl.at/jyKMX>. Acesso em: 30 jun. 2021.

RODRIGUES, Horácio Wanderlei. Ensino jurídico: saber e poder. São Paulo: Acadêmica, 1988.

RODRIGUES, Horácio Wanderlei. Novo currículo mínimo dos cursos jurídicos. São Paulo: Revista dos Tribunais, 1995. 
RODRIGUES, Horácio Wanderlei. Pensando o ensino do direito no século XXI: diretrizes curriculares, projeto pedagógico e outras questões pertinentes. Florianópolis: Fundação Boiteux, 2005.

SÁ NETO, Clarindo Epaminondas de; MENEZES, Caroline Rodrigues. Ensino e prática jurídica no Brasil contemporâneo: diagnósticos críticos. REJUR - Revista Jurídica da UFERSA, Mossor, v. 3, n. 6, p. 86-99, jul./dez. 2019.

SCHWARCZ, Lilia Moritz. O espetáculo das raças: cientistas, instituições e questão racial no Brasil. São Paulo: Companhia das Letras, 1993.

SIQUEIRA, Carlos Eduardo Pereira. O ensino jurídico é alienatório? Revista Direito e Práxis, Rio de Janeiro, v. 7, n. 13, p. 48-79, 2016. Universidade do Estado do Rio de Janeiro Rio de Janeiro, Brasil. Disponível em: <shorturl.at/jnsMY>. Acesso em: 29 jun. 2021.

VARGAS, Janete Correia; LOCATELI, José Henrique Pires; LOCATELI, Lucas Ribeiro. A relevância das concepções pedagógicas de Paulo Freire para o ensino jurídico na atualidade. Revista Jurídica da Faculdade de Direito de Santa Maria (FADISMA), Santa Maria-RS, v. 14., n. 1, p. 1-14, 2019. Disponível em: <shorturl.at/iylJ7>. Acesso em: 29 jun. 2021.

WOLKMER, Antonio Carlos. História do direito no Brasil. 9. ed. rev. e atual. Rio de Janeiro: Forense, 2015.

ZANARDI, Teodoro Adriano. Por uma docência jurídica emancipatória: contribuições freireanas ao ensino jurídico. In: CONGRESSO NACIONAL DO CONPEDI, 22., 2009, Manaus. Anais [...]. Manaus: Conpedi, 2009. p. 1260-1271.

Luiz Gustavo Tirolı: Mestrando no Programa de Pós-Graduação em Educação da Universidade Estadual de Londrina (UEL). Bacharel em Administração pelo Centro Universitário Filadélfia (UNIFIL). Discente do curso de Direito da Universidade Estadual de Londrina (UEL). Membro do grupo de pesquisas e estudos Currículo, Formação e Trabalho Docente da Universidade Estadual de Londrina (UEL), cadastrado e certificado junto ao Conselho Nacional de Desenvolvimento Científico e Tecnológico (CNPQ).

Orcid: https://orcid.org/0000-0002-7912-8319

E-mail: luiz.gustavo.tiroli@uel.br

Adriana Regina de Jesus Santos: Pós-doutora em Educação pela Universidade Federal Fluminense. Doutora em Educação pela Pontifícia Católica de São Paulo. Docente e Coordenadora do Programa de Pós-Graduação em Educação da Universidade Estadual de 
TIROLI, L. G.; SANTOS, A. R. de J.

Londrina. Líder do grupo de Pesquisa pelo CNPq: Currículo, Formação e Trabalho

Docente.

Orcid: http://orcid.org/0000-0002-9346-5311

E-mail: adrianatecnologia@yahoo.com.br

Este periódico utiliza a licença Creative Commons Attribution 3.0, para periódicos de acesso aberto (Open Archives Initiative - OAI).

Inter-Ação, Goiânia, v. 46, n. ed.especial, p. 1147-1163, set. 2021. Disponível em: <http://dx.doi.org/10.5216/ia.v46ied.especial.67735>. 